\title{
S B \\ 110
}

:: IN ::

WYOMING

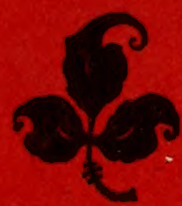

Propared by

DR. V. T. COOKE

Expert in

DRY FARMING

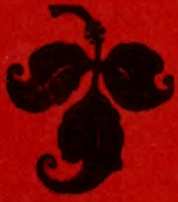

Published under Supervision of the

STATE DRY FARMING COMMISSION CHEYENNE, WYO, 


$$
\text { \% }
$$







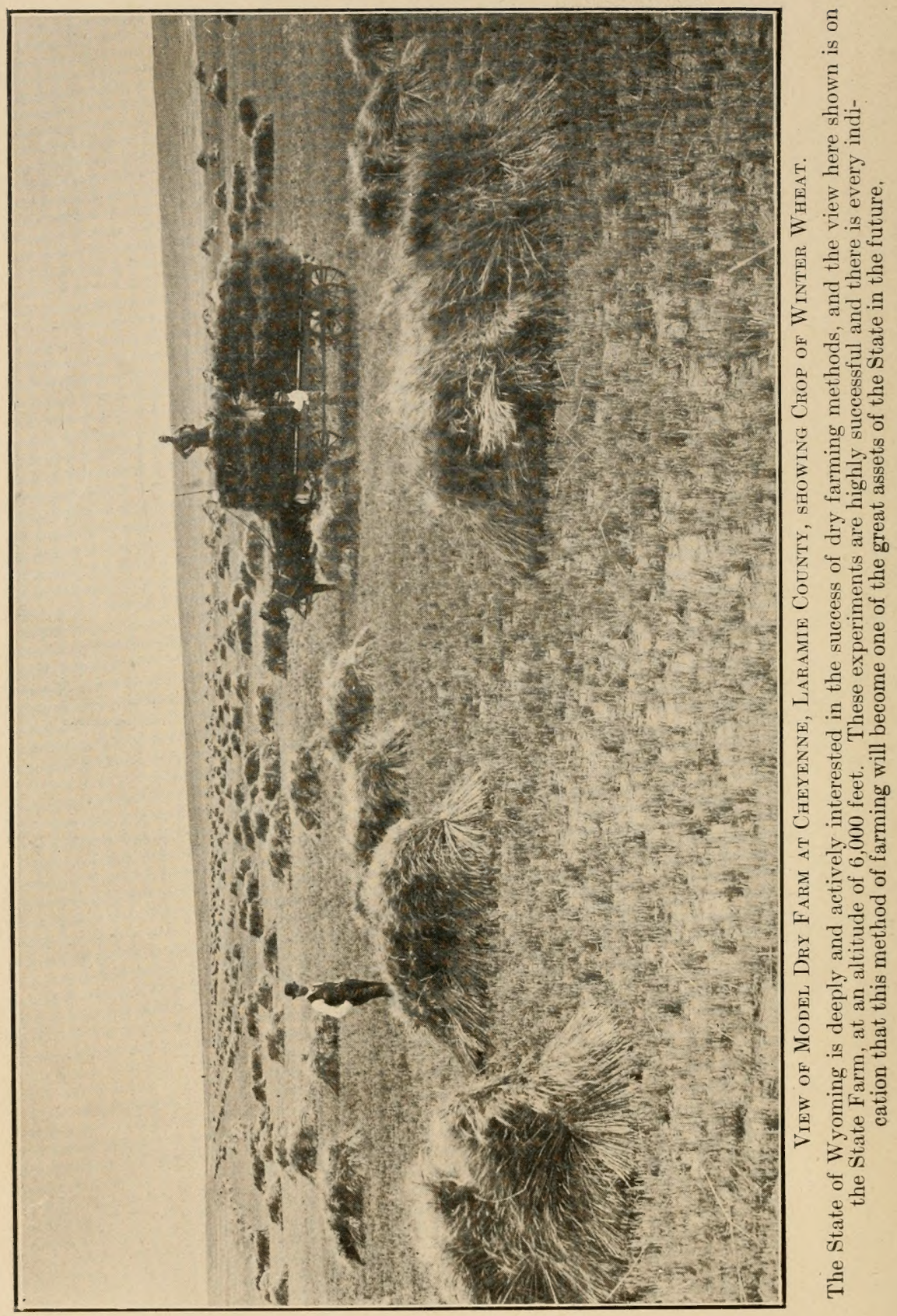




\section{DRY FARMING IN}

\section{WYOMING}

PREPARED BY

DR. V. T. COOKE

Expert in Dry Farming

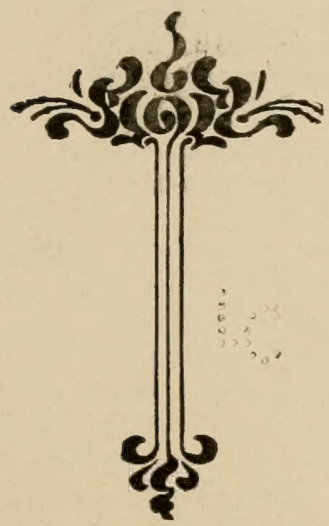

PUBLISHED UNDER THE SUPERVISION OF THE

STATE DRY FARMING COMMISSION

CHEYENNE, WYOMING 


$$
\begin{aligned}
& \text { SBI10 } \\
& \text { G13 }
\end{aligned}
$$

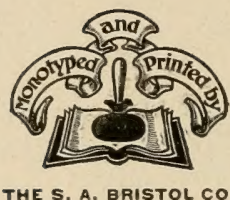

CHEYENNE, WYO.

$8^{4}: \vdots$
$2: 0:$

(C) Ang.311190\%.

c. 4246256 SEP $4 \quad 1909$ 


\section{DRY FARMING}

\section{IN

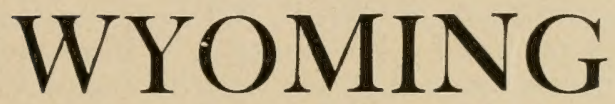

The term Dry Farming is somewhat new to the popular mind, and needs defining. The term is scientifically incorrect, and should be replaced by "Scientific Farming," as more nearly describing the special line of agriculture thus designated. From the general talk anyone would suppose that there were some special new methods, ideas and implements which must be used in order that Dry Farming may be a success. As a matter of fact Dry Farming is the oldest kind of farming, for crops have been raised since agriculture began with scanty amount of moisture furnished by rainfall. In the arid West, where it has been considered impossible to raise crops save by irrigation, Dry Farming means the raising of profitable crops where the rainfall is as low as eight inches per annum. This kind of farming has been practiced in California for over forty years and in eastern Oregon and eastern Washington for over twenty-five years. In these states it has been demonstrated that by deep plowing and a proper system of cultivation, two years' moisture may be held for one big crop. This is the system of summer fallowing and tilling one-half the farm area without crop each year, using the other half to produce crops. The apparent reason why systems of Dry Farming were not earlier established in Wyoming seems to be because of the failures which overtook those settlers who, in the early ' $80 \mathrm{~s}$, attempted to establish agriculture in Western Kansas and Nebraska, where the old methods which had been practiced under heavy amounts of rainfall farther east, failed to succeed. Farther west, as indicated, the two-year rotation system of Dry Farming has 
been long practiced with a rainfall which is less favorable in amount and time it is received than that in Wyoming. In parts of this State, however, notably along the eastern border and in the northeastern corner of this State, farmers have been subsisting by agriculture without irrigation for some years. Five years ago the Commereial Club, now the Industrial Club, of Chevenne, took up the matter, raised some funds for the purpose, and secured cooperation with the Irrigation Investigations, Department of $\mathrm{Ag}$ riculture, and the State Experiment Station for the establishment of a Demonstration Farm near Cheyenne. A company was also formed of private citizens to begin the development of this industry, and the Legislature in 1907 made an appropriation of $\$ 5,000$, placing it in the hands of Gov. B. B. Brooks, and another in 1909 of $\$ 10,000$ to be used by a commission of three gentlemen. The writer had been employed by the citizens' Committee and carried out two seasons' work, obtaining results which were very promising. These experiments were conducted almost within the city limits of Cheyenne. In the season of 1906,56 bushels of beardless barley and $38 \frac{2}{3}$ bushels of Macaroni wheat were raised to the acre, besides a large crop of oats, the yield of which was not computed. There were sown three tracts of alfalfa on one acre, five acres and ten acres respectively, and up to the present time these alfalfa fields give promise of being successful. There are numerous fields throughout the State in which alfalfa is being raised entirely without irrigation, and it is the opinion of the writer (from past experience where the conditions were not as favorable) that one big crop can be raised, and most likely a second if rain should fall at the right time.

When the money appropriated by the State Legislature became available, the writer was placed in charge of that work and, in addition to earrying out some demonstrations on convenient lands near Cheyenne, he is expected to assist anyone throughout the State interested in this work by giving information and advice. He can be reached at any time by addressing him at Cheyenne. It is the purpose of this paper to give the conditions in the State favorable to Dry Farming and compare them to those in other parts of the West where this kind of agriculture has been successfully practiced.

Of the total area of Wyoming, approximately one-half is still Government land open to entry, and it seems that about twenty million acres of the State can be brought under cultivation and made to produce profitable crops without artificial irrigation. Not only is the rainfall sufficient, if the moisture can be properly conserved, but it comes at a time when most needed by crops, which must add materially to the success of the farmer. 
The dates of precipitation show the following average in Laramie county for the entire period of record:

\begin{tabular}{|c|c|c|c|}
\hline 1871. & 9.27 & 1890 . & 14.47 \\
\hline 1S:2. & $13 . \times()$ & $1 \wedge 91$. & $1 \times 9 \%$ \\
\hline 1873. & 10.01 & 1892. & 13.50 \\
\hline 1 s.t. & 9.7 & $1 \wedge 9: 3$. & (1).2.2 \\
\hline 1575. & 12.10 & 1894. & 12.98 \\
\hline 1876. & 5.04 & 1895. & .14 .76 \\
\hline 1877. & 11.71 & 1896. & 20.79 \\
\hline 1875. & 12.64 & $189 \overline{7}$. & .17 .25 \\
\hline 1879. & 7.34 & 1898. & 13.05 \\
\hline 1880. & 8.38 & 1899. & .14 .18 \\
\hline $1 \mathrm{~S}$ & איצ. 11 & 1900. & 16.1199 \\
\hline 1882. & 8.64 & 1901. & .14 .99 \\
\hline 1853. & 19.24 & 1902. & 16.50 \\
\hline 1884 & 15.54 & 1903. & .12 .25 \\
\hline 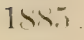 & $11 i .12$ & 19001 & 15.72 \\
\hline isS6 & & 1905. & 22.68 \\
\hline 1857. & & 1906. & .17 .65 \\
\hline 14kis & 14.51 & & \\
\hline 1899. & 14.65 & Average & .13. \\
\hline
\end{tabular}

The records will show that three-fourths of all this precipitation comes during the growing months. On the other hand, in Utah, Idaho, Eastern Oregon, Eastern Washington and California, where successful Dry Farming is established, the precipitation comes mostly in the winter time and not when crops need it nost. As a rule there is very little rain during that part of the year from spring to fall, and the wind blows fully as much, if not more, than it does in Wyoming, drying up much of the moisture. In Wyoming we are free from those scorching hot winds which prevail during certain seasons over large parts of the states farther west. There is another immense advantage in the distribution of rainfall and that is, by discing the stubble ground after copsine taken off, we conserve and hold what moist ure there is in the soil, prepare it so it readily ahsorbs what falls later, and this of ten enahlesusto plow the ground in the fall. This cannot be done where the dry season comes in the summer, for the ground is not in condition to be plowed in the fall, at least not until the fall rains come, hecause it is so hard and dry. The work at Cheyenne demonstrates that proper cultivation does conserve the moisture and keeps the ground in condition to be workerl. It must be remembered that for countless ages the virgin soils of Wyoming have been packed by buffalo and stock running over them and that there are im- 
mense tracts throughout the arid region where the soil has probably never been wet to a depth of two feet. After the breaking up of this surface, howerer, the moisture goes into the subsoil and is saved and accumulated so the conditions are entirely changed. These arid soils are rery rich in mineral plant foods and all of them have enough humus and nitrogen, when new, to support plant growth, and the occasional production of legumes, which gather nitrogen from the air, and plowing under a crop such as rye, alfalfa, sweet clover or peas, is all that is necessary to keep them perpetually fertile. It is a well demonstrated fact that any crops suitable to the latitude and altitude will produce large vields when raised by irrigation and it seems that with proper soil tillage we can do much without irrigation. Brief instructions for Dry Farming in those localities where the conditions are suitable are as follows:

At the higher altitudes in the State short season crops can probably be made to mature with less moisture than they can where the season is longer and comparatively hot. The general statement may be made that the soil conditions over large areas of the State are suitable to the conservation of moisture when it is properly tilled.

STsReir.

The system recommended for Wyoming is that which has been practiced in the arid portions of the West Coast States for more than a generation, with such modifications as are arlapted to our different conditions of soil, climate and rainfall. It consists in holding two years' moisture for one big crop. There are quite a number who misunderstand, when we speak of getting a crop every other year. It is true we only get a crop off the same land every other year, or under farorable conditions, say two rears out of three, but we must recollect that we get crops by this method when the seasons are dryer than usual and that we get one big crop with one plowing, one seeding, several cultivations, practically two year's moisture and one harvesting. The farmer simply divides his land into two portions, on one-half raising crops, the other half being summer fallowed. By this method, which is easily understood and carried out, the farmer has a long season instead of a short one and drives his work instead of being driven hy it.

\section{PLOWING.}

The plowing must be deep. The plan recommended in this State is to plow old ground eight or nine inches deep as early in the spring as possible so as to save all moisture as it falls. Plow 
stubble in the fall, when possible, in order that the ground may absorb the winter's moisture and allow the action of the weather to work on the plowed land.

HARROWING.

All spring and summer plowing should be thoroughly harrowed the same day it is plowed. It takes just as much time to harrow the plowed ground to-day as it does to-morrow or next day, other things being equal, but it makes much difference in the eniservation of the moisture when harrowing is done; besiles, harrowing same day, saves extra harrowing if left a few days. If possible, harrow (and drill as well) diagonally or at right angles to the way in which the prevailing winds blow. The olnject in doing this is to prevent the land from drifting or blowing; to hold the snow which falls on the plowed ground or winter grain, and to prevent the particles of soil or snow from injuring the young grain in the drill furrows by being carried along these furrows hy the wind. Other's have strongly recommended that those who are summer fallowing their ground should get on to it with the drag harrow immediately after any rain or snow. This is not always necessary, but what we must do is to get on to the ground as soon as it is dry enough after every heavy rain or big suow. This harrowing must not be deferred too long, because if we wait the surface of our soil will become very dry and is more liable to drift when we cultivate. The farmer must use his judgment and get on to the ground as early as conditions will be favorable to doing good work.

\section{Maintaining the Soll Mulch.}

The soil mulch is one of the most important factors in our success as Dry Farmers. It is by the soil mulch that we are able to conserve the moisture, prevent its loss by evaporation and absorbing all that comes to the soil by precipitation or from dews or other moisture in the air. The summer-fallow ground should be in a granular form of small lumps, but care should be taken not to get it too fine. The object of cultivating the summer-fallowed soil is to prevent the formation of a crust; to allow the proper action of the sun and air; to break up the capillaries and prevent the moisture rising to the surface and evaporating, and to intercept the growth of weeds. The moisture in the soil goes up and down by capillary movement and we keep our skil cultivated to break the upper connection and to prevent this loss of moisture. Sowing THE Crop.

Winter grain should be sown early, say not later than the end 
of August or beginning of September. 'This will give the grain a goord start and it will be in better condition to stand the winter. Spring grain should he sown ats early in the spring as the ground can be put in good condition and danger of hard freezing of the soil is past. It has hecome a recognized fact that we have been in the habit of making the very serious and great mistake of sowing too much seed per acre. The experience of the most intelligent and up-to-date farmers shows that by sowing thirty to forty pounds of wheat per acre in the fall, better results will be obtained than with more seed. One of the advantages of sowing a minimum amount of good seed on summer-fallowed ground and sowing it early in the fall is, that we make a lnng seasom of a short one, and, other things being equal, the eatlier the gratin is sown the greater is its chance of stooling. For the same reason we should sow a larger proportion of seed when we are late with the work in the spring. If the season is well advanced and the ground moist and warm the grain starts and grows so rapidly that it does not take time to stool. Another thing of vital importance in any kind of farming is to see that the seeds are planted properly, and, in the opinion of the writer, there is no greater mistake made than to practice broad-casting, either by hand or by a machine. When broad-casted the ground is harrowed or cultivated unevenlysome of the seed is too deep, some of it is not deep enough-and no doubt many failures are due to this method of sowing. The press chill is one of the essential implements for the Dry Farmer. It puts the grain in in proper shape and to the right depth, pressing the soil around the seed, which insures moisture to cause it to germinate, and there is much satisfaction in knowing that our work is done properly. We gain, in this way, a week or teu days by putting the grain into moist ground at a uniform depth. There is a large saving of seed also, and, where we are farming extensively, this is quite an important item, especially when we consider what first class seed costs. The man who sows alfalfa broad-cast generally puts in from twenty to forty pounds of seel per acre, when if he uses a press drill, ten to twelve pounds of seed will he sufficient, either under irrigation or dry farm practice.

SEFD to Usi.

There is $n o$ greater mistake made and one for which there is no excuse, by the man who wants results, (and that is what we are all after) than to use any but the best seed obtainable. Like produces like. Be sure and use those seeds that are raised without irrigation if it is possible to obtain them. It is most important to get seed which is thoroughly clean, free from weed seeds and all other impurities. The cost of such seeds is of very little im- 


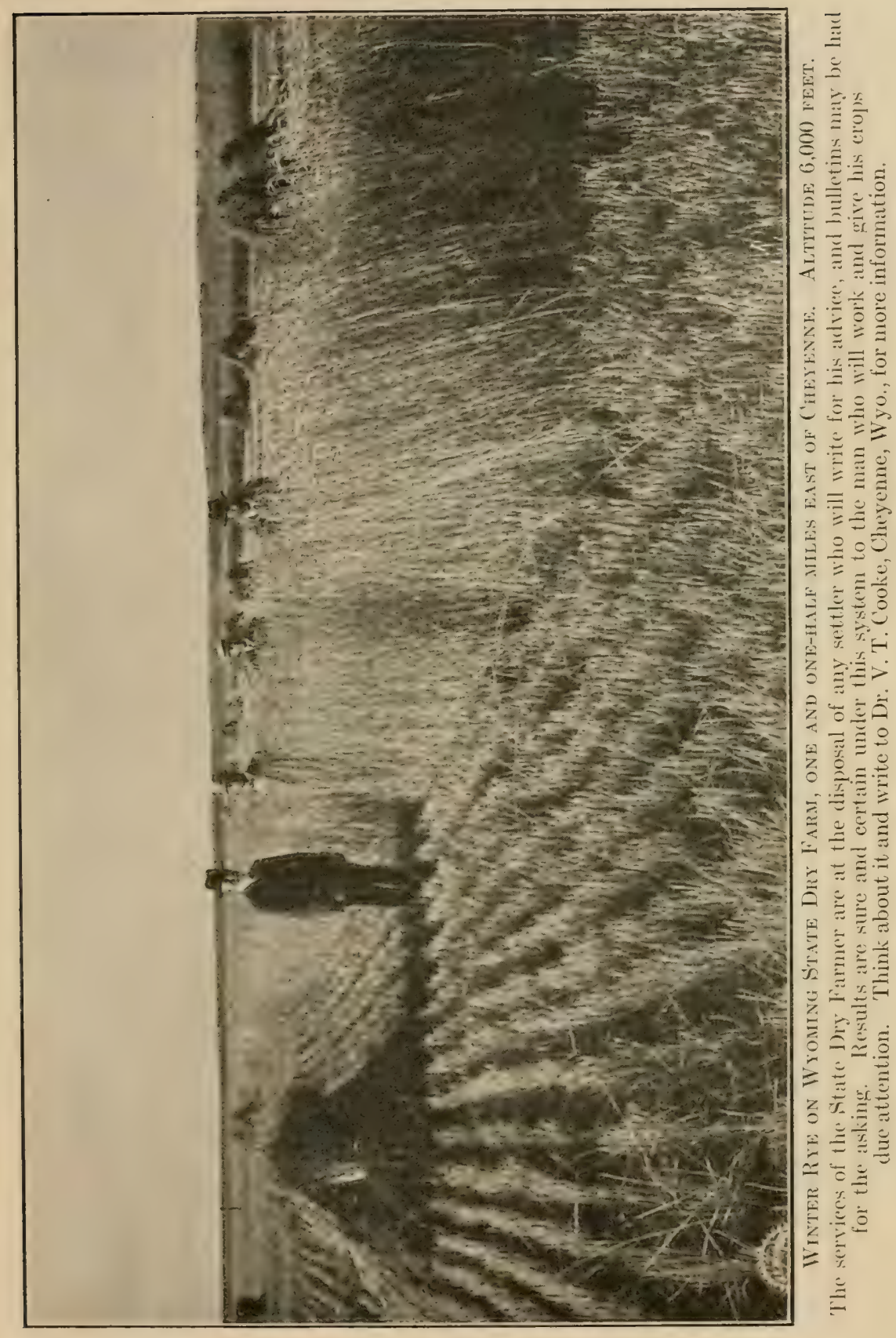


portance compared with the results which the best is sure to gire. Cultivatixg.

Under this system of farming a soil mulch must be maintained, not only on the fallow ground, where frequent harrowings will be all that is necessary, but also on the land which is raising the crop. In the spring thoroughly harrow your winter grain (or use a weeder) and remember that to do this properly requires that the harrow teeth must be sharp. Set harrow teeth slantingly. Harrow teeth like the top of a broom handle cannot do effective work. There are a large number of farmers who are actually afraid of harrowing their grain for fear of tearing out too much. We can only say, try it. The man who once harrows with a good team and sharp harrow teeth will not only have no cause to regret it but will see that it is always done in the future. I wish to emphasize the importance of cultivating growing cereals with the harrow or weeder. Alfalfa and grass meadows should be thoroughly disced. After the second year there is little or no danger of injuring alfalfa with the disc even though the surface soil is pulverized into a comparatively good seed-bed. Because alfalfa permanently occupies the land, diseing and harrowing is the only method by which the soil moisture can be properly saved and this is one of the secrets of success in this kind of farming. Use disc or alfalfa cultivator after every cutting. Potatoes, corn and other rowed crops should be harrowed up to the time they get too large, and after that shallow level eulture should he followed until the crop is laid by.

\section{HARVESTING.}

Of course the harvest may be carried on by ordinary methods, but the soil should not be neglected at this time. Where our rainfall comes during the summer, discing the stubble after harvesting grain is important. After harvesting potatoes or sugar beets the drag hariow should he used to heak up the lumps and re-establish the soil mulch. Barley or other grains that can be used for feed without threshing should be harvested when in the stiff clough. This prevents, in a measure, re-seeding the ground through the grain shattering out, for in this country all the ripe grain which drops on the ground in the fall comes up the next spring as a volunteer crop. If the grain can be fed without threshing it is narketed in the best possible way from the farm and saves the cost of threshing and handling.

Crops to RAISE.

Those crops which are grown in rows and only occupy a part 
of the grouud, like potatoes and corn, where the season is long enough, will mature with the least use of moisture. Among our small grains the drouth-resistant sorts are very important. Nacaroni or Durum wheat is one of the best. Polish wheat is a drouth-resistant sort and is good where it is to be used for stock feed. Spelt or emmer is a most excellent stock food and one of the best drouth-resistant sorts. Barley, either the bald or hulless or the beardless brewing barley, for feed, is a short season crop which will mature with a minimum amount of moisture. Oats do well in all parts of Iroming, the earlier varieties being best where moisture is scarce. Alfalfa will succeed, and it is important to get seed which is raised in the North where the seasons are short and in the arid country without irrigation. Where the season is long and warm, the sorghums make good crops. Brome grass is one of the best drouth-resistant crops for pasture purposes, but it quickly gets sod-bound and it must he harrowed or disced to keep it producing well. White sweet clover is being tested by the Experiment Station and leveloped by one of our plant breeders to so improve it that it will become a valuable crop for Dry Farming and an important feed with grain for use in fattening stock, especially lambs. French clover or sainfoin is a hardy drouth resisting clover at high altitudes. The winter grains are especially favorable for Dry Farming, because the summer-fallow method properly prepares the ground for such seed and the spring rains are sufficient to mature the crop. Winter rye is one of the most successful dry farm crops. Rye is not appreciated as it should be, for it is one of the best feeds for hogs that can be produced.

\section{Mixed FARMING.}

The best paying dry farms will be those in which a system of cropping and feeding stock is combined. Where the crops are fed to stock at the farm there is practically no loss of fertility. The manure is an important item to be added to arid soils as it increases their humus, making them more retentive of moisture as well as richer in plant food. As has been suggested also, where grains are raised for stork feed they may be cut early and fed in the bundle, which avoids the extra work of threshing and hauling to market. There are most excellent opportunities in Wyoming on account of our market facilities and favorable climate for finishinglambs or old sheep, cattle and swine, principally hogs of the bacon type, and such system of farming will be sure to bring the largest profit. 
Size of Farm.

One man with a small amount of extra help should be able to farm at least 160 acres by the summer fallow method. This denends on his knowing how to take advantage of conditions and on having the proper equipment. Four-horse tools pay. A man or boy with four good horses and a three-section harrow can harrow thirty to thirty-five acres per day. Using twice the power, hy having plenty of horses and double size machinery enables one man to do two men's work, which is the most erononial method.

\section{Equipatent Needed.}

Dry Farming does not require any special or new equipment. There are some things which are absolutely essential, however, if the dry farmer will make his business profitable. He should have four or six horses, a three-section drag harrow, a 2-12 or 14 inch gang plow, a good disc harrow, and the ones with the small dises do the best work. The dises should not be larger than fourteen inches, though most of them are now being made sixteen inches in diameter. An Acme harrow is a valuable instrument for maintaining soil mulch. The farmer will also need one or two good cultivator's and, if he has a farm large enough to pay, he will require his own harvesting machinery. It is sometimes most economieal for several farmers to club together and buy one harvesting machine rather than for each to have his own. The press drill is one of the essentials. This may be either of the shoe or the disc type. The double disc drill has some advantages where there is nuch stubble or refuse, like coarse manure on the ground, It is not necessary here to go into details of the farm buildings and fences required for they are something to be worked out according to the capital and tastes of each individual farmer. The point I would make in speaking of equipment necessary is that it does not require any new or complicuted or expensive machinery to do surcessful Dry Farming under the best methods.

$\mathrm{DO}-$

Plow deep, at least $S$ to 9 inches, more if possible.

Your plowing at the right time.

Your harrowing and cultivation as soon as the ground is dry enough.

Learn to take advantage of soil conditions.

Study the capability of your soil.

Sow a small amount of the best seed obtainable per acre. 
Fan ull seeds and use only the plumpest and cleanest seed possible.

Sow all seed with a drill. spring.

Harrow or use a weeder on all your growing grain in the harrow.

Cultivate your alfalfa or meadows by using a dise or alfalfa

Harrow your plowed ground as soon as plowed in the spring and summer.

Learn that eultivation conserves moisture.

Good and thorough work; it will pay.

Learn to rotate your crops and keep everlastingly at it and success is assured.

Realize there is always a ready morket for first class stock and that scrubs don't pay.

Make up your mind what you intend to do, make your plans accordingly and carry out your ideas.

Have an alfalfat or rye lot, or lather lots, for your hogs and growing pigs, and learn that to get results from these pastures it pays to feed some grain if only a little every day.

Get your alfalfa seed bed in the best possible state of tilth; learn that alfalfa fields will last indefinitely, provided you get a good stand, will cultivate them with in dise or alfalfa harrow thoroughly after each cutting, and will manure them.

Not forget that taking your crop off on four legs is one of the hest way's to make clear money off of your farm, besides improving its fertility by keeping all manure on your land. This method of farming, if earried out properly, makes your land of greater value year by year, and you will have larger returns from your work. In other words, feed your crops to those animals which you like best, be they cattle, sheep or hogs.

Not forget that to raise crops and feed them successfully, requires brains as well as muscle.

Keep in touch with your agrieultural college, get your name down for their bulletins and recollect that the professors are experts in their different lines, and that they will always he glad to assist and advise if you will only show your interest in their work by asking for information.

\section{DON'T-}

Plow when your soil is wet.

Harrow or cultivate your land when it is wet. 
Plow your ground in the fall and harrow it fine; it is liable to blow away or drift; leave it rough.

Use poor seed aud expect good results.

Sow your grain mixed with pernicious weed seed.

Over seed.

Sow broadeast.

Sow grain by hand and then run a dise over the land, and expect a good crop.

Sow alfalfa seed on sod ground.

Sow a nurse crop with alfalfa seed.

Forget to harrow the weeds as soon as they appear.

Let the manure go to waste.

Let the weeds grow, they are hard to get rid of when large, besides using up the moisture and fertility that crops need.

Forget that all soils are not alike and therefore cannot be treated the same. results.

Scratch your ground and call it plowing and expect good

Be discouraged if your crops do not meet with your expectations. It takes time to learn how to do things properly, besides: the season may not be favorable.

Forget that it is just as easy to get big crops as small ones; better seeds and better culture will increase yields.

Feed your horses oats in which there are more or less wild oats. horses with poor teeth cannot masticate or grind their food properly-result, wild oats are passed on to the ground where working.

Forget that scientific or expert farmers can not make hard and fast rules for every farmer. Farmers must study and work out their different conditions more or less for themselves.

Forget the federal government at Washington, D. C., issues bulletions on most, if not all, farm topies. These can be had for the asking, are written by men who make a special life study of their different departments. One very great objection is, they are too cheap; ask and you will receive.

There are exceptions to all rules. The above may not apply everywhere or to all conditions, but is worth the careful consideration of the man who is dry farming anywhere. 





\section{LIBRARY OF CONGRESS \\ |||||||||||||||||||||||||||||||||||||||||||||| \\ ||||||||||||||||||||||||||||||||||||||||||||||||||||||| 00009332509}

